\title{
The Generation and Dissemination of Agricultural Information to Farmers in Nigeria: A Review
}

\author{
LawalIro Sani; Boadi, B.Y. ; Oladokun, O.; Kalusopa, T. \\ Department of Library and Information Science,UmaruMusaYar'adua University, Katsina, Nigeria \\ Department of Library and Information Studies, University of Botswana \\ Department of Library and Information Studies, University of Botswana \\ Department of Library and Information Studies, University of Botswana
}

\begin{abstract}
Literature review is a comprehensive survey of the work published in a particular field of study or line of research, usually over a specific period of time, in the form of an in-depth, critical bibliographic essay or annotated list in which attention is drawn to the most significant work. This review will examine previous and current studies dealing with the events that have influenced the economic problems of Nigerian farmers. The review covers such area as: The concept of agricultural information, information generation output and types, information needs and assessment, users of agricultural research information, sources and access to agricultural information, the concept of information flow and the challenges/barriers of information dissemination were all reviewed.
\end{abstract}

\section{Introduction}

Agricultural information generation and dissemination are necessary for the development of agricultural products. Many initiatives have been put in place to create, to manage and to use agricultural information in Africa, particularly in Nigeria, to increase food productivity. For instance, Nigeria is a beneficiary of the Group of Twenty Countries (G20) to new agricultural initiatives. The G20 countries and the private sector have been working jointly with the Federal Government of Nigeria to generate research information that is aimedat increasing agricultural productivity. Indeed, the Federal Ministry of Agriculture is reported to have said that the G20 initiative will spur economic growth through increased agricultural productivity (Nigeria. Federal Ministry of Agriculture, 2011).

In addition,Ugwu and Kanu (2011) reported that various economic reforms have been carried out in Nigeria for over three decades in the agricultural sector. These initiatives are geared towards the achievement of food self-sufficiency and food security, generation of gainful employment, increased production of raw materials for industries, increased food processing of export crops and rational use of agricultural technologies for improvement of life. They also opined that poverty reduction, sustainable livelihood and food security, all of which guarantee comprehensive economic development and achievement of the Millennium Development Goals (MDG), can be achieved when initiatives are carried out in an environment that fully allows democracy and good governance. Ozowa (2008) attests that almost all countries in Africa lack adequate agricultural information dissemination policies, and where this is available, governments pay lip service to its implementation. To respond to this shortcoming, the United Nations Organization in 2010 came up with the Millennium Development Goals (MDGs) programme which addresses the African problems, particularly agriculture. The MDGs goal number 1(one) is as follows:

Represent human needs and basic rights that every individual around world should be abl e to enjoy freedom from extreme poverty and hunger; quality education, productive and $d$ ecent employment good health and shelter; the right of women to give birth with out risk t o their lives, and a world where environmental sustainability is a priority and women and men live in equality (Millennium Development Goal, $(2010,11)$.

This particular goal is important to Nigeria since poverty is one of the social problems thathas been bedeviling the country over the years. More so, its reality has been manifested in many severe incidences, despite the vast human, natural, economic and development potentials the country is blessed with (Ayoade, et al., 2011).

\section{Agricultural Information}

Having adequate and well-presented information will improve the efficiency of rural development, policies, projects and programmes. Agricultural information provision should be the basic component of rural development programmes. Oladele (2011) observed that lack of agricultural information is a key factor that has greatly limited agricultural advancement in developing countries. Thus, agricultural information interacts with, and influences, agricultural activities in a variety of ways. This tends to imply that agricultural information can help inform decision-making regarding land, labour, livestock, capital and management. Interestingly, 
agricultural information is not static but, instead, needs replenishment through research and development. This is why Opara (2008) reports that agricultural activities can arguably be improved by relevant, reliable and useful information and knowledge._Aina (1995), Mooko and Aina (2007) and others have reported in their research findings that agricultural information is an essential recipe for successful farming. One therefore sees that these same recipes can be used by Nigerian famers to increase productivity. However, information per se cannot increase productivity unless farmers are provided with the right type of information and at the right time, using the right channels and with all other necessary components in place, like telecommunication facilities, good roads, education, good agricultural policies. There appears to be other externalities that have to be in place so that information can make an impact. These significant externalities include such things as money, favourable socio-political stability, good governance, etc. (Radhankrishna, 2007).

Invwieri (2007) opined that, rural people (farmers) who are mainly illiterate require access to appropriate information to be able to make decisions and participate fully in the national development processes, including agriculture.

\section{Information Generation Output and Types}

Information generation is a process of creating, developing and communicating ideas which are abstract, concrete or visual. It is important to emphasize that the type of information generated revolve around scientific, commercial and legal information (Ballantyne, 2008; Demiryurek et al., 2009; Aina, 1995, Kaniki, 1995).

\section{Scientific Information}

Generally, agriculture is interdisciplinary in nature. For agriculture to be fully developed, farmers need information from different disciplines. Scientific information is one of the innumerable examples which is generated from universities and research institutes. In India, for instance, Chandrasekan et al. (2010), and Rao, (2007), opine that agricultural information in India is mainly derived from universities and research institutes. It includes scientific information which deals with research and development works carried out in universities and research institutes. Scientific information is aimed at providing information on new crops varieties, their requirements, and technical assistance during growing season. The characteristic of this information relates with climate, weather, drought and water stress periods, water sources, quality and availability.

In Turkey,Demiryurek et al. (2008) argue that agricultural research is usually carried out in research institutes and the objectives of such institutes are to provide farmers with information on best practices. Demiryurek further noted that as a result of information dissemination to dairy farmers in Turkey, functional cooperation between public and private information sources in the system is needed to motivate conventional dairy farmers to convert into modern dairy farming systems. Emad-Kharasani (2009:17) in Iran seem to concur with Demiryurek et al. view that, "Nowadays, scientific and technical information is considered as a basis for material and intellectual sources in different societies and any society which is able to access more information automatically has more potentiality".

Oladele (2006) hold the view that agricultural information is generated in universities and research institutions. This result emanates from a research on multilingualism of farm broadcast and agricultural information access in Nigeria. Oladele, (2006) also pointed out that such information includes scientific and commercial information. It is indicative that research and development has the ability to create a pool of scientific and technical information with a great wealth in modern societies. Therefore, research and development departments existing in the various universities in Nigeria are a platform for creating material intellectual sources which can enhance Nigeria's wealth.

Demiryurek, et al. (2008), Opara (2008) and Ekpenyong (2001) all provide further evidence that agricultural information is generated from universities and research institutes. They report that information generated from these institutions include, among others, information on pest and weed control, weather forecast, credit facilities, fertilizer and legislations on agriculture generally. Indeed farmers in Nigeria, like their counterparts from Asia and other parts of Africa, need scientific and technical information because it is among the most important information needed for wealth creation and national development. This is corroborated by Ugboma (2010) in a study on access to agricultural information by fish farmers in the Niger Delta region of Nigeria, where it reveals that 98 percent of fish farmers studied prefer scientific information.

\section{Commercial Information}

Commercial information is another type of information generated by research institutes as well as the universities. This information deals with price control, price of fertilizers, price of seeds, and sale of agricultural products. Maru (2008) and Renwick (2010) in separate studies carried out in India and the Caribbean respectively reported that research institutes are behind the generation of commercial information that is related to markets. This type of information is related to production, productivity and profit enhancement. It therefore covers information on commodity price, food quality and safety as well as labeling information. Maru (2008) 
asserts that agriculture is an interdisciplinary activity that requires information from different disciplines and that commercial information is a key to farmers who sell their produce. The fact that farmers require diverse information has been echoed by various researchers including those in Lesotho where Mokotjo and Kalusopa (2010:352) attested that farmers need to have access to agricultural information in order to improve their agricultural production and that farmers need to have access to financial information for their actual performance as well as access to credit".

In a related development, Opara (2008) support the fact that agricultural information is generally generated in universities and research institutes and that such information pertains to credit facilities, fertilizer and legislations on agriculture generally. The study was based on agricultural information sources used by farmers in Imo State, Nigeria.

Similarly, in Nigerian context,Ugwu and Kanu (2011) maintain that most of the agricultural information in Nigeria is generated from universities or commercial outlets as to where a farmer can find fertilizer, credit facilities, cost of inputs and its quality, transaction costs, labour supply and demand, distribution, selling options, agricultural insurance, market price and quality requirements. The availability of commercial information enhances farmers' performances and without it, farmers will be skeptical as to what to produce, how to locate, potential market to sell their produce. To buttress the point that farmers in Africa need commercial information, Meyer and Boon (2003) buttress that South African farmer's wanted information on how to give loans and the repayment of such loans. The next section will interrogate literature that relate to legal information.

\section{Legal Information}

These are generally laws grouped under the heading "agricultural laws", that relate to the production activities, as they are carried out in a commercial setting (Kaniki, 1995). There are numerous Nigerian statutes that subsidize, regulate or otherwise directly affect agricultural activity. These cover any law promulgated by either a state, federal or local government. These may deal not only with plants and animals but also with land use, environmental rules, and the use of food products. Hence, with the increasing sophistication of farming process, issues of intellectual property, trade, finance, credit and generally commercial transaction often arise. All legislations that affect agriculture such as land tenure, the production, distribution and sales of agricultural produce come under this category of legal information (Aina, 1995). This type of information will be the domain of extension workers, policy makers and farmers.

From the foregoing, it may be said that farmers wherever they are, require diverse information, whether scientific, commercial, or legal as long as that information hinges on the success of what they do. Consequently, any farmer who sells his produce will need commercial information, in the same way that he or she will need information about the weather, soil, buyers, loan facilities, etc. Therefore universities and other institutes which produce interdisciplinary information are very crucial to farmers in Africa who need different information to improve yields and production. In a related development, Ozowa (2008) in a study contends that agricultural information is generated through research efforts from universities and is categorized as: (i) agricultural technology, (ii) agricultural credit and (iii) marketing. His contribution is based on a study on information needs of small scale farmers in Nigeria

These findings confirm that farmers in many parts of Africa, and Nigeria in particular, require technical information about pest control, new seedlings, use of machines and other equipment. Farmers all over the world require a range of information from the weather, loans, soil, seeds, farming mechanisms, control and management, harvesting, storage, marketing, sale, investments and repayment of loans (Opara, 2008).

An investigation of empirical literature reveals that agricultural information output is varied and extensive, hence, it needs to be generated, disseminated and be used by specific farmers based on their different needs Oladele, (2011);Ballantyne, (2009); and Ozowa, (2008). Some of the evidences from the review clearly show that not all information that is generated reaches the end user.Similarly, the research findings of Aina (1995) are still reminiscence of today's occurrences, where it was reported that sometimes the form of information generated for farmers is not used because of the medium of communication, time allotted to air agricultural pogrammes, the language used in communicating information, and the attitude of the end user (farmers).

So far, the review shows a disconnection which may be one of the contributing factors why generated agricultural information has not been sufficiently used in Africa. A striking example is Nigeria, where most rural famers are illiterate and most of the information generated from universities and research institutes have not been stepped down to suit the end user.

\section{Information Needs and Assessment}

Due to the complexity of the problems facing irrigation farmers, there are varieties of information needs of farmers. This is especially imperative in an information dependent sector like agriculture. But one major issue is 
thatmajority of farmers in Africa are illiterate and therefore need information in a simplest and quickest way to discharge their duties effectively. Information needs has been defined by Kaniki (1995: 25) "as the state of lack of desirable requisite(s) or commodity i.e., information, necessary to deal with a situation as the individual sees fit". People often talk about information needs when, in fact, they are referring to wants or use. While both are plainly manifestation of need- and should be considered as such, they are different and do not fully or accurately describe need. According to Nikolas (2005), information needs arise when a person recognizes a gap in his/her state of knowledge and wishes to resolve that anomaly- as anomalous state of knowledge. This turn out to be time given, by adding that it is the information that individuals require to do their job effectively. The farmer cannot be an exception.However, most people do not have information needs per se. Rather, they experience a problem or difficulty or are under some pressure, and these cognitive and emotional needs may be met, or partially met, by obtaining and then applying that information (Nikolas, 2005). Information needs arise out of a desire to meet one or other of the three basic human needs: physiological needs (need for food, shelter.); psychological needs (need for domination, security) and cognitive needs (need to plan, learn a skill) (Kaniki, 1995, Nikolas, 2005).

Therefore, in this increasingly information dependent age, the lack of information could certainly have serious, or even, perilous consequences for the individual. Information is needed in all stages of human development. People need information in learning new skills. Human beings are regarded as an information seeker regardless of age. For information to be of optimum use, it must have the following qualities: relevance, accuracy, timeliness, currency, clarity and must be cost effective (Vidanapathrina, 2012).

Many a times, farmers do not always know what their information needs are. They do not know they have an information gap. It could be that they are not aware that there is information out there that could help them to a great deal. They also do not know that new information has rendered obsolete what they previously knew. As a result, this leads to a quest for new information which arises, in that it is so much needed by the farmers. It is only when they are exposed to the relevant information that the need is recognized, this is called dormant need (Nikolas, 2005). The other type of information need is unexpressed need. This is a situation where users are aware of their information needs, but do nothing about them, either because they cannot or will not disclose their information needs. Many people are unaware of what the information service can do for them so they do not make demands upon it. Of course, people may want information they do not really need or which is unsuitable- perhaps, their initial perception of its value does not match with reality or, maybe, they just use what is close to hand or what they are aware of (Ballantyne, 2009).

While illustrating a point, Kaniki (1995), used the scenario of a farmer who has two types of fertilizers to choose from for application in his field. In order to apply one type of fertilizer, the farmer would have to reach a decision as to which of the two types of fertilizers to use. This process is called critical task. Therefore, one of the commodities required in this process is to arrive at a good decision is information.

In conclusion, it can be said that, whether the information need is identified by the information seeker or expert, expressed or unexpressed, and where levels of need of similar information need differ. It is the task of information experts in all these instances to provide appropriate information to meet these needs; and to successfully use ICT to support farmers and rural communities, the first step is to empower farming communities to define their own need (Ballantyne, 2009).

As at the fall of the new millennium, human beings are devoting more and more attention to system reform across multiple sectors including agriculture. Particularly in this era of rapid technological advancement and continuing system reform, it is appropriate and critical to assess the impact of such reforms and development in farming. This can only be done through need assessment. The main reason for undertaking needs assessment must be that the information profession has neglected doing so in the past and that has not got the information profession very far, and, indeed, continue to frustrate its progress.

It is evident that in most information work stations, information experts are unable to commit enough time to conduct full-fledge scientific studies to analyze information needs of individual farmers who face critical situation or information needs (Kaniki, 1995). Through the anomalous state-of- knowledge (ASK) approach several critical tasks in Africa, have been identified. These include:

Situations where researchers need to have basic understanding of research results before applying suc $\mathrm{h}$ results; situation where researchers have to make choice among the different cropping method $\mathrm{s}$ and different types of soil suitable for particular crops, vegetables and fruits. Other situations include: the investigation into, diagnosis and treat ment of different diseases that affect crops, vegetables etc; th $\mathrm{e}$ analysis and it is prediction of yields and the forecasting of climatic and weather patterns....(Kaniki,1 995:25).

However, according to Nikolas, $(2005,6)$ there are several factors that contribute towards the neglect of information user needs, these are:

* There are information professionals who feel that it is not necessary to consult client in what they consider to be, professional matters; 
* Information professionals tend to be preoccupied with information systems and not the users of these systems;

* The profession is plague by insular attitudes and poor communication skills, something that does not lead to close relationships with the consumer;

* The expenditure of resources involved in the obtaining of needs data is not thought to be justified in these hard budgetary times;

* An absence of a standard, commonly understood framework for the assessment of information needssomething, which it has to be said, lets information professional off the hook;

* It is by no means easy getting hold of the necessary needs data.

From the foregoing, it is evidently clear that, information generators (researchers) and policy makers need to come to terms to what farmers and particularly farmer's need before they embark upon providing them with the generated information. Although information needs of farmers are varied as their characteristics, hence they need to be consulted on the type of information they need. This is due to the fact that most of the farmers are either subsistence farmers, large scale or even part-time. Although the subsistence and part-time farmers do not deal with intricate agricultural activities similar to large scale or commercial farmers but yet they need to be consulted, informed and advised before they are confronted with new research and innovations.

Agriculture progresses as farmers adopt innovations from researchers. The extent to which farmers adopt innovations and the speed by which they do so is determined by assessing their information needs. To achieve this, farmers must be linked with the appropriate information that will help them solve their information needs. Due to lack of information need assessment, and untimely information, unavailability and unreliable information farmers are forced to take a wrong decision thereby jeopardizing their sustenance and national growth (Chandrasekan, et al., 2010).

\section{The Users and usefulness of Agricultural Research Information in Nigeria}

People can only use the available information at their disposal which is dependent on provision and access. In theory, the more information that is accessible the more it is likely to be used. Therefore, for information to be used there must be potential users who need that information for their day to day activities and there must be those that generate the information.

From the foregoing, it is evident that information is a very important tool for agricultural development. This is so, because some of the developed nations of the world occupy their coveted positions in food security by virtue of information generation and delivery to their people. It is therefore equally desirable for African governments and the Nigerian government in this case, to intensify efforts in the provision, dissemination and use of agricultural information by the farmers at all levels in order to achieve self-sufficiency in food and Gross Domestic Product [GDP] of their countries. Similarly,Opara (2008) has noted that in agricultural information there lie the potentials which can definitely boost agricultural production and in the end create a profound impact on policy makers, researchers and the farming communities in Africa including those in Nigeria.

Aina (1995) has categorized the various agricultural information user populations as follows:

* Farmers

* Policy-makers

* Extension workers

* Agro-allied industries.

Each of these sectors contributes directly to the improvement of agriculture. When relevant information is provided to each category, it will contribute to the development of agriculture in any part of the world. In Nigeria, like most African countries, some of the most frequent users of agricultural information are farmers, policy makers, extension workers and agro-allied industries.Farmers

Farmers are people who cultivate the land for either subsistence or large scale farming. They can also be engaged in livestock farming. Farmers are key consumers of agricultural information for their sustenance and for national development. Agricultural information is meant for all types of farmers. However, specific farmers will require specific information relevant to their trade. In agriculture, there are many types of farmers. But the three major groups constitute: crop farmers, livestock farmers and livestock/crop farmers. Crop farmers usually grow a wide variety of different crops, including wheat, barley, flax, corn, canola, lentils, oats, cotton or mustard, etc. (Rao, 2007), while livestock farming is about raising animals like goats, pigs, sheep, cattle, camels, poultry, etc. Livestock/crop farming involves cultivating the land as well as engaging in livestock farming.

The potentials of agricultural information to farmers have been reported by Vidanapathirana (2012) for him, agricultural information within the hands of the farmers means empowerment through control over their resources and decision-making processes. This assertion makes it very clear that when farmers are bestowed with information, they become empowered and are able to make positive changes in their farming activities. Indeed, Vidanapathrina (2012) notes that an effective and efficient delivery system of essential information and technology services to farmers will facilitate their critical role in decision-making towards improved agricultural production, processing, trading, and marketing. 


\section{Policy-makers}

These are mostly government officials and sometimes include persons from quasi-government or parastatal bodies (Kaniki, 1995). Similarly, Chisita (2010) reports that governments all over the world play a central role in formulating agricultural policies and mobilizing extension workers to reach farmers. Similarly, government policy makers through legislation also generate and use especially social, commercial and legal information (Aina, 1995). A summation of these views shows that there is a significant relationship between legislative information generated and used by policy makers and farmers. This is because most of the acts and laws on agriculture have direct bearing on farmers and the general improvement on agriculture.

\section{Extension Workers}

Beside farmers, the other consumers of information are the extension workers. These are people who are employed by government and have a certain level of education to bridge the gap between the government and the farmers. These groups of people pass on information to farmers or even educate them on how to use information derived from research institutes. It is this information in the hands of farmers that empowers them to take control over their resources and decision-making processes and increase productivity (Vidanapathirana, 2012).

The role of extension workers has further been elaborated by Ballantyne $(2009$,$) in a study which describes$ extension workers and policy makers, researchers and agro- allied firms as beneficiaries of agricultural information. However, extension workers alone are not sufficient tools to disseminate agricultural information. Instead, other channels like the radio, community leaders, the barefoot librarian and many other players are critical in making this happen. In Nigeria, the small number of extension workers and policy makers is an issue that has contributed to low yields in the rural areas (Banks, 2011). However, the various roles and contributions the few extension workers and policy makers continue to make in the current food production cannot be downplayed.

Nigeria's first involvement in a conscious and purposefully planned agricultural extension was at the time of British colonization. According to Gwyne and Jones (2010:122) the colonial masters introduced extension and extension work "in an effort to encourage farmers to increase agricultural production both for home consumption and for export and also to impose on farmer's government rules and regulations". With independence and subsequent developments, various governmentsintroduced changes in the nature of extension work but the objective has remained the same, that of bridging the gap between farmers, researchers and policy makers (Gwyne and Jones, 2010). Agricultural extension, according to Gwyn and Jones (2010), is a significant social innovation. It is an important force in agricultural change which has been created and recreated, adapted and developed over the centuries. Van-den-Ban (2009) reports that in several countries, for example, India and Iran, extension work mainly places attention on the adoption of innovations, while in many former communist countries, much attention is on investment and marketing decisions.

Hosseini, Mehrad and Gholamreza (2009:1479) in another development points-out that: "agricultural extension worker has an important role in promoting the adoption of new technologies and innovations. The trend from su pply driven extension to demand driven extension requires a new approach". They further posit that extension workers in Iran have a key role in brokering between providers of communication technologies or services and their potential customers. Consequently, extension workers must be able to examine the appropriateness of various ICTs and their accessibility in both rural and remote areas. This suggests that in addition to their role in bridging the gap of information dissemination, extension workers can play the role of suggesting the best ICT tool to use within a particular farming community.

Evenson and Germano (2001), in their analysis of the role of extension workers in Kenya, posit that a national system of agricultural extension can play an important role in increasing farm yields but its effect on yields is not uniform across farmers. This indicates that because of individual differences among farmers, not all the farmers will adopt the innovations provided to them by the extension workers.

In another investigation on the role of ICT in the provision of agricultural information to small scale farmers in Harare, Chisita (2010) explores some of the roles of extension workers. For him, extension workers play a critical role in providing agricultural professional services, farmers training, advisory and technical support to farmers. Similarly, an investigation on the perception of trust and employees' attitudes in Nigeria by Ladebo (20 06:410) stresses the role of extension workers in agriculture. Extension workers in the developing nations are ex pected to promote market oriented agriculture, assist the poor farmers to cope with vulnerability and help in poverty reduction in the rural areas. This suggests that, the role of extension workers is not only that of disseminating information generated to farmers but they are also expected to assist in how to sell their produce, buy seedlings and control of pests, all in an effort to fight food insecurity in the country.

Agricultural research output constitutes an important knowledge base that should be made available to farmers through sources that are not only acceptable to them but also accessible. Thus, the identification of the different 
sources of information, information services being used by users (farmers) is needed to bring out the relevance of these sources and services as well as the relevance assigned to the different types of sources and services.

From the foregoing, one could say, the intellectual level and orientation of the extension workers must elicit the confidence of farmers, with whom they interact. Extension workers need to understand adequately, the environment they are serving before they start to disseminate the agricultural information they have acquired. The essence of environmental scanning according to Jorosi (2008) is in the acquisition and use of information about events, trends and relationship or organizational external environment, the knowledge of which would assist the management in planning the organizations future course of action.

An efficient, dedicated, adequately trained and well-oriented extension worker is essential for maintaining a healthy productive channel of communication and change between research output and the farming community. This is because agricultural information output is varied, extensive, and therefore needs to be generated and disseminated to specific farmers based on their differentiated needs.

\section{Agro-allied Industries}

These are corporate entities working in full symbiosis operation with the agricultural industry by providing or deriving goods or services to other industries dependent on them (Chandrasekan, et al.2010). In the view of Kaniki (1995) and Chandrasekan, et al. (2010), agro-allied industries personnel are another subgroup of agricultural information user population. Most of these personnel are educated beyond secondary school level of education and are employed in private agricultural industry. What is apparent from this study, when it is compared with other studies cited, is that extension workers, policy makers, and agro-allied industries have similar perceived information needs. It is also clear that agricultural information must be generated and disseminated through an acceptable medium that is easy to handle and also use a language that is intelligible to all the information users.

\section{Sources and Access to Agricultural Information}

Any system producing or containing information intended for transmission is an information source. Information sources are distinguished by the form of representation; textual (books, journals, manuscripts), graphic (graphs, diagrams, plans, charts), and audio visual (sound recordings, motion pictures, slides). The characteristics of a good information source are relevance, timelessness, accuracy, accessibility, cost effectiveness, reliability, usability, exhaustiveness and aggregation level (Feather and Sturges, 2004). Oladele (1999) stresses that the efficiency of technologies generated and disseminated depend on effective communication which is the key process of information dissemination. Therefore, it is expected that the message from the client should be passed back to the source or researchers for the communication process to be complete. Despite the attempts at technological innovation transfer, the wide gap between the levels of production which research contends is attainable and that which farmers achieve, suggests a missing link (Oladele, 1999). What is more, weak linkages between the farmer, extension workers, and researchers mean that the farmers are not included in the planning of the innovation hence; they do not know where to get information, despite the fact that they are the end users. Agricultural information disseminated by different information sources needs to be determined. It is imperative therefore to identify the sources of agricultural information utilized by farmers.

Opara (2008) investigated the overall sources of agricultural information available to farmers in Imo State (Nigeria), as well as the farmers' preferred sources. The study reveals that $88.1 \%$ of the farmers' source of agricultural information was through extension agents. Similarly, Ozowa (2008) shows that among all the existing channels of communication, Nigerian farmers ranked extension workers the highest in providing credible information and advice. The investigation was carried out on small farmers in Imo state, Nigeria.

Mokotjo and Kalusopa (2010) in their survey study found out that print sources are among the sources of information to farmers in Lesotho. Their study reveals that, though most of the farmers have acquired primary education, the agricultural information delivered to them is written in local languages. This enables them to utilize the information effectively. It also demonstrates the high literacy level in Lesotho and indeed according to the literacy rate in Africa, Lesotho occupies the seventh position with a literacy rate of 84.80\% (Aneki, 2012). However, only $13 \%$ out of $61.7 \%$ of the farmers in Lesotho are of the view that prints media is one of the appropriate technologies to disseminate information. However, Lwoga, Stilwell and Ngulube (2011) significantly differ from Mokotjo and Kalusopa (2010). For them, print materials have low usage due to their unavailability and illiteracy levels of most of the farmers in Tanzania.

The mass media also provides support for the growing involvement of farmers/producers and their organizations in the information dissemination arena. The rapid development of information technologies has profoundly changed the media landscape in African countries. Information and Communication Technology (ICT) is a term that combines computer and telecommunications technology in handling, acquiring, processing, storing and disseminating information (Chauhan, 2009; and Malhan, 2007). Information and Communication Technology is 
a general or an all-inclusive term that embraces all those technologies that are employed in collecting, storing, organizing and communicating information in various forms (Chisita, 2010).

ICT can become a key enabler of the agricultural-food sector by making dynamic and real time global level exchange of data as stated by Rao $(2009,492)$ "Effective deployment of ICT can lead to increase in agricultural competitiveness through cuts in production and transaction costs, raising production efficiencies and farm incomes, conserving natural resources, and by providing more information, choice and value to stakeholders". In using ICT successfully to support farmers and rural communities, the first step is to empower farming communities to define their own needs (Ballantyne, 2009:356). With wider access to and use of ICT, the potentials of opening up of communication as well as sharing information would be enhanced, so as to assist farmers, researchers, extension workers and policy makers. It will also narrow the information gap that exists between the farmers and the researchers on the other hand because there will be a feedback (Ballantyne, 2009). In the same view, Renwick (2010), points out that, most of the small island nations are above the $100 \%$ and some are over $200 \%$ mobile phone penetration mark. This implies that many people had more than one cell phone and over $100 \%$ of the farmers used cell phones to receive agricultural information. This indicates that ICT is a very useful tool in the dissemination of agricultural information to the farmers especially in rural areas where cell phones have been embraced by both literate and illiterate farmers. Therefore ICT has become the most important tool that is crucial in processing and disseminating agricultural information. In the same string of thought, Bolarin and Ayanlade (2010) maintains that mobile phones and computer systems are the most used and widely owned tools today by extension workers and their organizations in the North Central Zone of Nigeria. This is because, about $75 \%$ of the respondents surveyed by Bolarin and Ayanlade (2010) perceived themselves as frequent users of multimedia and other ICT tools.

Other sources of information for farmers that are equally important, but less recognized are the traditional sources. The traditional system is the form of information emanating from colleagues, during weddings, naming ceremonies, burials, agricultural shows and festivals and in some cases through town criers (Aina, 1995). Demiryurek et al. (2008) argues that Dairy farmers in Turkey use four categories of information all of which are traditional sources of information relayed from family members. The four categories are: extension workers, posters and leaflets, family members, and the electronic media.

In the Caribbean, farmers rely heavily on traditional knowledge and informal meetings among themselves for farming (Renwick, 2010). Questions as to what to plant, what moon phase is best for sowing seeds and transplanting seedlings, and how often to rotate crops are answered through colleagues. This suggests that, one of the sources of information to farmers in the Caribbean is the traditional source which is transmitted through oral channels by colleagues. This is harmonized with the situation obtainable in Nigeria as reported by Aina (1995). Similarly, Opara (2008) reported that agricultural information in its broadest sense includes indigenous agricultural knowledge (IAK) which is transmitted orally from person to person. This is a very common practice in Nigeria and hugely relied on by old farmers as well as the illiterate and many others who favour oral dissemination of information. Oral tradition is an important method of disseminating agricultural information in many African cultures. This is because it recognizes existing traditional or indigenous channels of information dissemination.

Lwoga, et al. (2011) in their study on access and use of agricultural information and knowledge in Tanzania reports that the major sources of information for farmers are predominantly local (neighbors', friends and family) which implies that their major sources of information are traditional. To emphasize the importance of traditional information in Africa, Aina (1995) points out that one of the sources of information of farmers in Nigeria is traditional. That is information is obtained not from official sources directly but through colleagues or family members. Aina holds the view that, though the majority of the farmers in Africa are illiterate, it is possible to supply them with necessary information through the information gate- keepers popularly known in North Western Nigeria as SARKIN NOMA (Information gate keeper), who is a literate farmer among the farming community with a wealth of experience and vast land. The role of a SARKIN NOMA is to offer advice and information on a regular basis to other farmers for improvement. The contention by Ugboma (2010) buttresses the various studies cited, where in a study conducted on access to agricultural information by fish farmers in the Niger Delta Region of Nigeria, Ugboma observed that $63 \%$ of the respondents indicates that, their source of information is through traditional, as well as personal experience.

\section{Barriers to Information Access and Utilization}

However these farmers have been facing many challenges in relation to information generation and communication which lead to low output in production and sustainability. These include, but are not limited to, lack of sufficient agricultural knowledge and information that will enhance farmers participation, collaboration and integration; lack of investment from other agricultural stake holders, for example, agro-allied industries, government and non-governmental organizations; illiteracy level is too much in the area as most of the farmers lack access to formal education. Language is another crucial issues this means the language of communicating research findings. There are also politics in taking decisions from government officials; poverty condition of the 
farmers for which reason they are unable to procure machines and high definition equipment that will enable them to compete with time. Failure to prioritize agriculture especially by government of Nigeria and that of North Western States; ineffective ICT policies that are geared towards informing farmers through the ICT tools and where they are available, there is poor access and reception. What is more, there is near absence of training and re-training of both the extension workers and farmers on new innovations as the extension workers are not adequate to take care of the teeming population of the farmers.

\section{References}

[1]. Aguolu, C.C. (1989). Libraries, Knowledge and National development.In augural lecture series No 45.Delivered at University of Maiduguri, Nigeria.

[2]. Aina, L. O. (1991). Information for successful agriculture. Journal of Library and Information Science, 2(1), 1-6.

[3]. Aina, L. O. (1995).Information and agriculture in Africa. In: Aina, L. O., Kaniki, A. M., and Ojiambo, J. B. (eds.), Agricultural Information in Africa, Ibadan, Nigeria: Third World Information Services, 1-11.

[4]. Ayoade, A. R., Ogunwale, A.B., and Adewale,J.G. (2011). Impact of the national special programme for food security on poverty $\begin{array}{llllll}\text { alleviation among } & \text { Oyo } & \text { State, } & \text { Nigeria. } & \text { African }\end{array}$ Journal of Food, Agriculture, Nutrition and Development, 11(4), 5065- 5082.

[5]. Ballantyne, P. (2009). Accessing, sharing and communicating agricultural information for development: an emerging trends and issues. Information Development, 25(4), 260- 271.

[6]. Bolarin, O. and Ayanlade, A. (2010). Utilization of satellite imaging and information communication technology in agricultural information dissemination in Nigeria. Journal of Agricultural and Food Information, 11(4), 351-357.

[7]. Cary, M. and Bolasubramani, R. (1997).Information seeking behavior of Tapioca (cassava) growersinSalemDistrict.Journal of library philosophy and practice.

[8]. Chandrasekan. $\quad$ S., Dipesh,D.M., Jitendra, K.J.D., Kamlesh,J. $\quad$ S., $\quad$ andDinesh, $\quad$ K.J.N. (2010).Context aware mobile service deployment model of agricultural information system for Indian farmers. International Journal of Computer Application, 1(29), 8-12.

[9]. Chauhan, A. V. (2009). Use of ICT (Information and Communication Technology) in Technology Libraries. Journal of Library Philosophy and Practice.

[10]. Chisita, C. T. (2010). An investigation in to the use of ICT in the provision of agricultural information to small scale farmers in Harare. World Library and Information Congress: Procceding of the $76^{\text {th }}$ IFLA General Conference and Assembly, Gothenburg Sweden.1- 14.

[11]. Demiryurek, K.; Erdem, H., Ceyhan, V. Atasar, S., and Uysal, O. (2008).Agricultural information systems and communication network: the case of dairy farmers in the Samsun province of Turkey. Information Research, 13 (2). 1320. Paper343.

[12]. Emad-Kharasani, N. (2011). The role of information services in agricultural development of Iran: A progress report, 130-134.

[13]. Ekpenyong, G. D. (2001).Agricultural research in Nigeria.The role of institutional libraries.Information Development, 17(2), 118-122.

[14]. FAO.(2005). Agricultural knowledge and information systems for rural development (AKIS/RD) Strategic vision and guiding principles. Sustainable Development Department (SD), Food and Agricultural Organization of the United Nations (FAO)..

[15]. Ibrahim, R. Levitt, R. and Ramsey, M. (2002). Discontinuity in Organization: impacts of knowledge flows on organizational performance.

[16]. Invwieri, J. W. (2007). Information needs of illiterate female farmers in Ethiope East local Government Area of Delta State, Nigeria. Library Hi Tech News, 9(10), 12-24..

[17]. Kaniki, A.M. (1995).Agricultural information user population and critical task in Africa. In: Aina, L. O., Kaniki, A. M., and Ojiambo, J. B., (ed). Agricultural information in Africa, Ibadan, Nigeria, Third World Information Services, 12- 31.

[18]. Lwoga, E. T, Stilwell, C and Ngulube, P. (2011). Access and use of agricultural information andknowledge in Tanzania. Agricultural information and knowledge. Library Review, 60(5), 383-395,

[19]. Malhan, I. V. (2007). Agricultural knowledge transfer in India: a survey of prevailing communication channels. Journal of Library Philosophy and Practice.[1-12].

[20]. Maru, A. (2008). A Normative model for agricultural research information system.19- 25 .

[21]. McCue, J., Craycraft, C., Dunham, T., Fretz, T., McGeachin, R., Wilson, P., and Young, E. (2005).Stocking the shelves.Leadership Council for agricultural information and outreach. Sub-committee on content report. Council of the U.S. Agricultural Information Network (USAIN).

[22]. Mchombu, K. (2003). Information dissemination for development: An impact study. Journal of Information Development, 19(2), 111-126.

[23]. Meyer, H.W.J., and Boon, J. A. (2003). Provision of agricultural information for development: A case study on crossing communication boundaries. Libri Journal, 53. 174-184.

[24]. Millennium Development Goal Report (2010). We can end poverty 2015. United Nation,

[25]. Mooko, N. and Aina, L. O. (2007).Information Environment of Artisans in Botswana.Libri Journal, 57. [1-7].

[26]. Mokotjo, W. and Kalusopa, T. (2010). Evaluation of the agricultural information service (AIS) in Lesotho.International Journal of Information Management, 30, 350-356.

[27]. Nigeria. Federal Ministry of Agriculture (2011).Federal Ministry of Agriculture.Bulleting no.3. Abuja, Government Printer.

[28]. Nigeria. National University Commission (2013). Federal Government Approves 3 New Universities.8 (2).

[29]. Nikolas, D. (2005).Assessing information needs: Tools, Techniques and Concepts for the Internet Age $2^{\text {nd }}$ Ed. ASLIB Taylor and Francis e-library.

[30]. Oladele, O. I. (1999).Extension communication methods for reaching small-ruminant Farmers in South Western Nigeria in: Proceedings of the $26^{\text {th }}$ Annual Nigerian Society of Animal production Conference, Kwara Hotels, Ilorin.

[31]. Oladele, O. I. (2006).Multilinguality of farm broadcast and agricultural information access in Nigeria. NordicJournal of African Studies, 15(2), 199-205.

[32]. Oladele, O. I. (2011).Effect of Information Communication Technology on agricultural information access among researchers, extension agents and farmers in South Western Nigeria. Journal of Agriculture and Food Information, 12, 167-176.

[33]. Opara, U. N. (2008).Agricultural information sources used by farmers in Imo State, Nigeria.Information Development, 24(4), 289-292. 
[34]. Oyedele, D. (2012).Illiteracy and its risk for women. Paper presented at the $2^{\text {nd }}$ International Conference on Education and Educational Psychology.

[35]. Ozowa, V. N. (2008). Information needs of small scale farmers in Africa the Nigerian example. Quarterly Bulleting of the International Association of Agricultural Information Specialist, 40(1), 1-6.

[36]. Radhakrishna, R. B. (2007).Approaches for linking markets and farmers to foster indian'srural development. Proceedings of the $24^{\text {th }}$ Annual Meeting, E.A.R.T.H. Costa Rica, 1-17.

[37]. Rao, N. H. (2007).A frame work for implementing information and communication technologies in agricultural development in India. Journal of technological forecasting and social change, 74, 491-518.

[38]. Reddy, D. E. (2008). Holistic view of agricultural information transfer systems.World Library and Information Congress in: Proceedings of the $74^{\text {th }}$ IFLA General Conference and council, Quebec, Canada. 1-7

[39]. Reitz, J. M. (2003).Dictionary for library and information science. India. Rain Tree.

[40]. Renwick, S. (2010). Current trends in agricultural information services for farmers in Trinidad and Tobago Caribbean in: Proceedings of the $76^{\text {th }}$ IFLA, General conference and assembly, Gothenburg Swede.1-12.

[41]. Samuel, G. S. (2001). The development of integrated management information system for agricultural extension institutions of developing Countries: The Case of Oromiaagricultural development Bureaus. Published PhD. Dissertation.ISBN3-8265-85690 . Shakar Verlag, Aachen, Germany [online].

[42]. Ugboma, M. U. (2010).Access to agricultural information by fish farmers in Niger Delta region of Nigeria. Journal of Library Philosophy and Practice, [1-7].

[43]. Ugwu, D. S. and Kanu, I. O. (2011).Effect of agricultural reforms on the agricultural sector in Nigeria. Journal of African Studies and Development, 4(2), 51-59 12]

[44]. Vidanapathirana, N.P. (2012). Agricultural information systems and their applications for development of agriculture and rural community, a review study. 1- 14 . 